\title{
UNIVERSA MEDICINA
}

\section{Pterygium: degeneration, exuberant wound healing or benign neoplasm?}

\author{
Nurbuanto Tradjutrisno*
}

\begin{abstract}
Pterygium is a condition characterized by the encroachment of a fleshy triangle of conjunctival tissue into the cornea. Despite various studies, the pathogenesis of pterygium remains unclear. Chronic exposure to sun is the only factor of which the role has been clearly documented by epidemiologic and in vitro studies. Recent studies have provided data such as loss of heterozygosity and microsatellite instability, decreased apoptosis, increased growth factors, increased p53 expression, telomerase activity, and presence of oncogenic viruses, which support the concept that pterygia can be considered a neoplastic condition. Some of results are contradictory and some features were only found in a proportion of pterygia; this may be due to differences in methodology and study population, but may also be indicative of multiple causative factors. This implies that the pterygium should be viewed as a final common outcome of various etiological factors, such as geography and ethnicity, with ultraviolet radiation-induced damage as the main factor. Thus the pterygium remains an enigma, having the features of an exuberant growth but also those of a benign neoplasm. In this connection there is a need for a unifying theory capable of explaining all of the characteristics of the pterygium.
\end{abstract}

*Department of Ophthalmology, Gatot Subroto Central Military Hospital, Jakarta

\section{Correspondence}

dr. Nurbuanto Tradjutrisno,SpM Department of Ophthalmology, Gatot Subroto Central Military Hospital Jl. Abdul Rahman Saleh No.24, Jakarta Pusat Phone: 021-3441008

Email:

ntradjutrisno@gmail.com

Univ Med 2009;28:179-87

Keywords: Pterygium, apoptosis, growth, neoplasm

\section{INTRODUCTION}

Pterygium is a chronic disease that is characterized by an aggressive invasion of fibrovascular tissue into the cornea, and is one of the most common ocular surface diseases in tropical and subtropical zones. ${ }^{(1)}$ Many suffer from this aggressive disease and its prevalence in the general population has been estimated to be 7$13 \%$. ${ }^{(2,3)}$ Two frequently encountered lesions of the conjunctiva are pterygia and pingueculae ${ }^{(4)}$ Pterygia have been known since antiquity and theories about their pathogenesis have been proposed for a comparable length of time. One of the theories that should be mentioned is that of Fuchs, described in 1892. ${ }^{(5)}$ Fuchs postulated 
that the pingueculum is the forerunner of the pterygium. Modern ophthalmology usually describe pterygia as degenerations of the conjunctiva originating from pingueculae, which have been considered as precursors of pterygia. However, Kanski ${ }^{(4)}$ is of the opinion that pterygia may represent a response to chronic dryness and ultraviolet exposure, and does not mention any relationship with pingueculae. ${ }^{(4)}$ The association of pterygia with chronic exposure to sunlight and dryness had also been noted. ${ }^{(6)}$

The term "pterygium" (pteron = a wing) usually refers to a triangular lesion on the conjunctiva, but may also designate winglike or weblike structures in other locations, such as the neck or elbows. Thus the pterygium of ophthalmology should properly be called "ocular pterygium" or "ophthalmic pterygium". Omission of the label "ocular" may result in the inclusion of non-ocular pterygia in Internet searches based on the key word "pterygium", eg. multiple pterygium syndrome. ${ }^{(7)}$

In connection with recent advances in research on pterygia, this mini-review aims to summarize some of the current views on the pathogenesis of pterygia.

\section{Pterygium morphology}

A pterygium is usually described as a fleshy triangular growth located in the interpalpebral fissure, most frequently on the nasal side. The lesion starts growing from limbal (or corneal) stem cells in the limbal epithelium and invades the cornea centripetally, eventually covering the pupil. A typical pterygium consists of the apex or head, the collarette or collar, the body and the edges. The apex is the part of the pterygium that invades the cornea as a raised whitish growth firmly adherent to the cornea. Behind the apex is the collar, which represents the limbal portion of the pterygium and is continuous with the apex. The apex is preceded by a hood or cap, which is a crescent-shaped grayish avascular patch on the corneal epithelium around the apex. In front of the hood under the corneal epithelium there are small irregular areas of grayish opacity called Fuchs' patches, and a fine yellow-green crescentshaped line (Stocker's line) resulting from hemosiderin (iron) deposits in Bowman's layer. Stocker's line is a morphological marker of a chronic inactive pterygium; in rapidly advancing lesions there is no time for the accumulation of the iron. The body is the main fleshy part of the pterygium, trapezoidal in shape and highly vascularized. It has winglike lateral extensions (the edges) consisting of conjunctival folds that demarcate the pterygium from the normal conjunctiva. ${ }^{(6,8)}$ The iron deposition in Stocker's line has also been said to originate from tear film lactoferrin. $^{(9)}$

The main histological features of a pinguecula are elastotic degeneration of the collagen fibers of the conjunctival stroma, thinning of the overlying epithelium, and occasionally calcification. A pterygium has essentially the same features as a pinguecula, but with more neovascularization and thickening of the conjunctival epithelium. In addition, there is also destruction of Bowman's layer and the superficial corneal lamellae.

An in vivo study of 20 primary pterygia from 15 patients by confocal microscopy using the newly developed Heidelberg retinal tomograph II (HRT-II) with cornea module. Their observations showed that the vascularization of the pterygium formed loops at the leading edge of the head of the pterygium and did not extend into the healthy cornea. ${ }^{(6)}$ In front of the pterygial head groups of cells could commonly be observed that were more refringent than the corneal epithelial cells. These cell clusters had indistinct outlines and corresponded to Fuchs' patches (ilots de Fuchs). Occasionally the region in front of the head took the form of an irregular refringent band, which was more marked in active pterygia. 


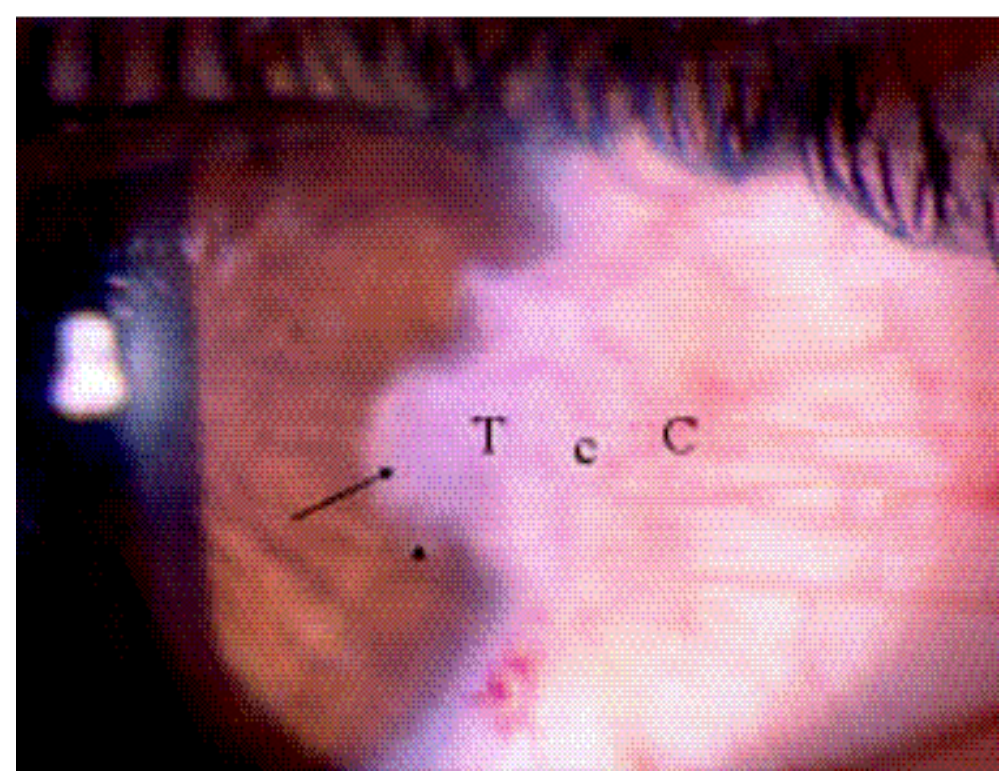

Figure 1. Pterygium morphology(6)

Legend: $\mathrm{T}=$ head of pterygium; $\mathrm{c}=$ collar of pterygium; $\mathrm{C}=$ body of pterygium; arrow = progressive zone of Fuchs; arrowhead = Fuchs's patch

In terms of growth characteristics, a pinguecula may occasionally enlarge very slowly, but seldom requires surgical excision. In contrast, a pterygium ultimately progresses towards the visual axis, when surgical excision is indicated. Recurrence of pterygia after surgical removal is a particularly difficult problem, for which may solutions have been proposed, such as postoperative administration of beta-radiation, thiotepa, or mitomycin, none of them being completely satisfactory. ${ }^{(9)}$

\section{Ocular surface biology}

The normal ocular surface is composed of two types of epithelia, conjunctival and corneal, each with a distinct cellular phenotype. The nonkeratinized conjunctival epithelium contains mucin-expressing goblet cells, whereas the corneal epithelium is a non-keratinized stratified epithelium expressing the cornea-specific keratins $\mathrm{K} 3$ and $\mathrm{K} 12$ and has mucin-expressing non-goblet superficial epithelial cells. The limbus or corneoscleral junction is the transitional zone between the conjunctiva and cornea, and contains corneal stem cells, also known as limbal stem cells. This finding was a major advance in ocular surface epithelial biology, as this discovery led to many other research studies. ${ }^{(10)}$

In 1997 it was proven conclusively that corneal progenitor cells are localized in the limbus, by culturing limbal cells from patients with complete loss of the corneo-limbal epithelium into sheets of corneal cells and subsequently restoring the patients damaged cornea by grafting of autologous corneal sheets. ${ }^{(11)}$

\section{Characteristics of pterygia}

The commonly accepted features of pterygia may be summarized as follows: Pterygia 


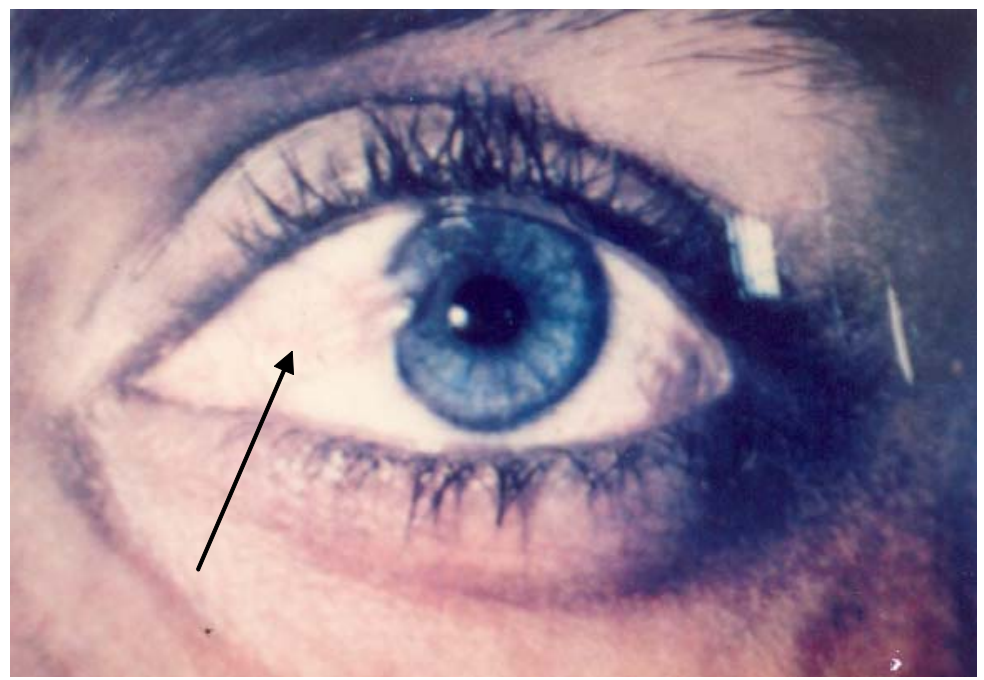

Figure 2. Pterygium (arrow)

originate in the limbal epithelium from altered limbal basal epithelial cells as a result of ultraviolet (UV) radiation induced damage. The limbal cells invade the cornea centripetally followed by conjunctival epithelium. Bowman's layer is dissolved under the leading edge of the pterygia, while vascularization occurs in the conjunctiva adjacent to pterygia. It should also be noted that pterygia have a high recurrence rate. ${ }^{(12)}$

\section{Pathogenesis of pterygium}

Currently, theories on the pathogenesis of pterygium cannot give a completely satisfactory explanation of this enigmatic lesion. Theories that have been proposed include inflammatory influence, degeneration of connective tissue, genetic instability, angiogenesis, redox related toxicity, cellular proliferation, aberration of apoptosis, exuberant wound healing, altered lipid metabolism, mast cell infiltration, and stem cell dysfunction. $^{(13)}$

Dushku and Reid ${ }^{(14)}$ found nuclear p53 expression without apoptosis in the limbal epithelia of pterygia, limbal tumors, and most pingueculae. A study also found overexpression of p53 in 7 of 14 pterygia. ${ }^{(15)}$ Subsequently Dushku et al. ${ }^{(12)}$ demonstrated elevated expression of matrix metalloproteinases (MMPs) in pterygium cells. MMPs are ubiquitous proteolytic enzymes that are controlled by natural antagonists, the tissue inhibitors of metalloproteinases (TIMPs). The MMPs modify or degrade extracellular matrix components in normal and remodeling tissues, and are found in many diseases. These enzymes are secreted by a variety of cell types including fibroblasts and are categorized into five groups: collagenases (MMP-1, MMP-8, MMP-13), gelatinases (MMP-2, MMP-9), stromelysins (MMP-3, MMP-10, MMP-21, MMP-22), membrane type MMPs. ${ }^{(16)}$ Proposed that pterygia actually consist of two tumors, where the main tumor is the pterygium itself, while the second tumor is formed by a group of fibroblasts (the pinguecula) within the pterygium. ${ }^{(12)}$ This condition is also seen in other ocular and skin tumors with elastotic stromal degeneration. The pterygium arises from UV-induced alterations in the p53 gene of limbal (corneal) basal epithelial cells, whereas the pinguecula originate from mutations in the elastin gene of limbal fibroblasts. The 
fibroblasts make abnormal elastotic material and express multiple types of MMP, which are also produced by the limbal epithelial cells.

The p53 gene mutations are active mutations resulting in a damaged programmed cell death mechanism (apoptosis), thus leading to acquisition of mutations in other genes. This allows for the multistep development of pterygia from p53-expressing limbal basal epithelial cells. The p53 mutations may also lead to overproduction of TGF-b via the p53-Rb-TGFb pathway; thus pterygia may be considered to be TGF-b secreting tumors. Excess secretion of TGF-b results in elevated MMP expression by pterygium cells (altered limbal basal epithelial cells) as well as by activated normal fibroblasts under the invading limbus epithelium, both leading to dissolution of Bowman's layer. Some of these cytokine-activated fibroblasts migrate anterior to the leading edges of pterygia between Bowman's layer and the basement membrane of the corneal basal cells to form little islands of fibroblasts (ilots de Fuchs) that make MMPs, again helping to dissolve Bowman's layer. ${ }^{(12)}$

However, in a more recent study, the investigator found no p53 gene mutations in Caucasian pterygia. In their revised theory, the accumulation of p53 protein without causing apoptosis may be the result of inactivation of the p53 protein. ${ }^{(17)}$ In contrast, their molecular analysis of p53 gene mutations in eight Chinese pterygia detected mutations in all samples, with six substitutions and two deletions. ${ }^{(18)}$ Additionally, a study showed statistically significant overexpression of p53 in around $35 \%$ of 31 Ecuadorian pterygia, which were also 8-hydroxy deoxyguanosine $(8-\mathrm{OHdG})$ immunoreactive. ${ }^{(19)}$ Moreover, a study in Brazil found abnormal p53 expression in 14 of 36 pterygial specimens, and HPV DNA in 21 of them. ${ }^{(20)}$

Support for Dushku's statements on the role of MMPs in pterygia may be found in the results of a Chinese study, in which the investigators reported overexpression of MMP-1 and MMP-9 in primary pterygium. They also found overexpression of TGF-b1, which may lead to hyperplasia of collagen fibers and accumulation of metamorphic fibers. ${ }^{(21)}$ In contrast, the Brazilian study on MMP-9 expression in 42 primary and 19 recurrent pterygia found no significant difference in MMP-9 expression between the pterygia and normal conjunctiva. ${ }^{(16)}$

Pterygia do not erode through the full thickness cornea and thus are distinct from malignant tumors. In their view, the pterygium is a mixed soft tissue tumor that is strongly associated with non-ionizing UV radiation. ${ }^{(13)}$ As the investigators note, in this respect the pterygium is highly unusual, because UVinduced tumors in humans are generally of epithelial origin, while UV radiation effects on keloids, if any, are commonly inhibitory. The pterygium is also unusual because researchers have been unable to discover an analogous tumor in animals or reconstitute the disease in organ cultures. The implication is that pterygium involves species-specific mechanisms mediated by in vivo cell-cell or cell-matrix interactions. The molecules involved in this disease may have therefore arisen from divergent evolution in the human ocular surface. The origin of the epithelium overlying pterygial lesions to be still unclear, although suspected to be conjunctival. This view is at variance. ${ }^{(12)}$ who maintain that in the pterygium the migrating limbus is followed by conjunctival epithelium, implying that the epithelium covering the body of the pterygium is of conjunctival origin. ${ }^{(12,13)}$

The global gene expression study used the U133A microarray, and the microarray data were subsequently validated by relative quantitative real time polymerase chain reaction $(\mathrm{qPCR})$ and immunohistochemistry. The study revealed that several genes were upregulated, while apostosis genes were downregulated in pterygium. The upregulated genes included fibronectin (FN1), 
carcinoembryonic antigen (CEACAM5 or CEA), CD24, SPARC, microseminoprotein (MSMB) and TFF1. The downregulated genes coding for apoptosis were TGM2, IGFBP3 and DUSP1. This down-regulation of apoptosis in pterygium reinforced the over-proliferative tendency of the lesion. ${ }^{(13)}$

A similar study had been conducted previously by John-Aryankayalil et al. ${ }^{(22)}$ In this study, over expression was found of novel and previously identified extracellular-matrix-related, proinflammatory, angiogenic, fibrogenic, and oncogenic genes in human pterygium. There was one notable difference, in that the CLIC2 gene was down regulated in a study, ${ }^{(22)}$ but significantly upregulated in other study. ${ }^{(13)}$

The winglike shape of a pterygium and the mechanisms supporting its centripetal growth have also been investigated. The concomitant breakdown of the limbal barrier and subsequent conjunctivalization of the cornea may explain the shape and formation of a primary pterygium. Because the growth pattern of pterygia mirrors the radial arrangement of corneal nerves, advanced the hypothesis that directional growth of pterygia may be facilitated by neuropeptides. ${ }^{(23)}$ In support of their hypothesis, the researchers found that substance $P$ at nanomolar concentrations induced cell migration in pterygium fibroblasts and vascular endothelium in a dose-dependent fashion, which was inhibited by an NK1 receptor antagonist. On the other hand, pterygium epithelial cells were not migratory in these experiments. They therefore concluded that NK1 receptors are present in pterygia and that substance $\mathrm{P}$ is a potent chemoattractant for pterygium fibroblasts and vascular endothelial cells. Thus substance P may contribute to the shape of pterygia through its profibrogenic and angiogenic action. ${ }^{(23)}$

UV irradiation of biological tissues may induce a direct phototoxic effect or an indirect effect through formation of radical oxygen species
(ROS). ROS damage cellular proteins, lipids, and DNA in a process known as oxidative stress. In addition, ROS can induce cyclooxygenase 2 (COX 2) formation via activation of the NF-kB signaling pathway. Both ROS and COX 2 were found to play the most important role in UVrelated cutaneous carcinogenesis. Because pterygium is currently considered to be a UVrelated tumor, a study in Taiwan demonstrated cyclooxygenase- 2 expression in the epithelium of 90 pterygia. ${ }^{(24)}$ UV radiation-induced DNA lesions caused by ROS have been associated with initiation and progression in a multistage model of carcinogenesis. A most typical oxidative lesion product is $8-\mathrm{OHdG}$, since guanine is the most easily oxidized naturally occurring base. $8-\mathrm{OHdG}$ frequently mispairs with adenine during DNA replication, leading to G-C to T-A transversion, and thus gives rise to mutations. It has also been established that it is a sensitive marker of oxidative DNA damage. G-C to T-A transversions, induced by the presence of 8-OHdG during DNA replication, have also been observed in the ras oncogene and p53 in human skin cancers of sunexposed areas and in UV-induced mouse skin cancers. In their study of 31 Ecuadorian pterygia, Perra et al. ${ }^{(19)}$ found $8-\mathrm{OHdG}$ in $21(68 \%)$ specimens, and p53 expression in 11 (35\%). A study had previously reported the ocurrence of a G-C to T-A transversion in exon 6, codon 213 of $\mathrm{p} 53$, which is typical of oxidative lesions, and also the presence of $8-\mathrm{OHdG}$ in $23 \%$ of 52 pterygia samples. ${ }^{(25)}$

The in vivo confocal microscopy study of Gheck et al. ${ }^{(6)}$ substantially confirmed previous observations on the features of pterygia. In their view, ultraviolet radiation causes micro traumas that are responsible for the inflammatory lesions. Certain UV-sensitive tumor supressor genes (p53) may play a role in the pathogenesis of pterygia, whilst other factors, such as dust, wind, heat and dryness, are of secondary importance. Their theory is based on localized areas of 
dryness of the conjunctiva (dellen) due to destruction of the lipid layer of the tear film, leading to an increased evaporation. These dellen induce a cicatrizing response with the proliferation and growth of inflammatory conjunctival tissues. It is notable that the mucus produced by the pterygium differs from normal conjunctival mucus. The cellular proliferation, inflammation, modification of conjunctival tissue and angiogenesis are dependent on the presence of growth factors such as fibroblast growth factor (FGF), platelet-derived growth factor (PDGF), transforming growth factor (TGF) and tumor necrosis factor- $\alpha$ (TNF- $\alpha$ ), some of which are produced by the fibroblasts. ${ }^{(6)}$

A study found increased telomerase activity in pterygia compared with normal conjunctival tissues. ${ }^{(26)}$ They studied 27 tissue samples from pterygia, in which 14 epithelial tissues from pterygia (51.9\%) were positive for telomerase activity, whereas telomerase activity was positive in only three of 9 normal conjunctival tissues $(33.3 \%)$, although there was no significant statistical difference between pterygium-covered conjunctival epithelia and normal conjunctival epithelial tissues. Telomerase functions by maintaining a constant telomere length, thus ensuring the retention of chromosomal stability attributed to functional telomeres and alters the cell's biological clock, effectively preventing a cell from aging. Telomerase activity is usually found in immortal cells such as germline cells, stem cells, malignant cells, cells from some types of benign and premalignant skin tumors, and also in cutaneous tissues chronically exposed to UV radiation. Because pterygia are believed to be also caused by chronic UV radiation, Park et al. ${ }^{(26)}$ searched for telomerase activity in pterygia, with the abovementioned results. The researchers suggest that the difference in telomerase activity between normal conjunctival epithelium and that of pterygium may be caused by an activation of telomerase or a clonal expansion of telomerase positive cells due to chronic sun exposure.

To elucidate the role of angiogenesis in the pathogenesis of pterygia, Aspiotis et al. ${ }^{(27)}$ investigated the microvessel density and the expression of vascular endothelial growth factor (VEGF) and thrombospondin-1 (TSP-1) in tissue sections of 52 pterygia and 7 normal conjunctiva. The researchers found a higher microvessel density and an increased level of VEGF in pterygia as compared to normal conjunctiva, and a statistically significant positive correlation between microvessel density values and pterygial VEGF expression. On the other hand, there was a low level of TSP-1 expression in approximately half of the pterygia.

The contribution of cellular immunity to pterygium pathogenesis was studied in Turkey by Tekelioglu et al. ${ }^{(28)}$ who found higher rates of intercellular adhesion molecule-1 (ICAM-1)positive cells, vascular cell adhesion molecule1 (VCAM-1)-positive cells, human leucocyte antigen (HLA)-DR-positive cells and CD4 and CD8 lymphocytes in pterygium tissue samples.

Finally, in a more recent review of pterygium pathogenesis, apart from the previously mentioned factors, such as UV radiation, limbal stem cells, oxidative stress, growth factors and cytokines, the possible pathogenetic roles of altered phospholipase D, human papilloma virus (HPV) involvement and Ki-ras proto-oncogene mutations are discussed. ${ }^{(9)}$

\section{Pterygium: benign neoplasm?}

Pterygium and papilloma are benign conjunctival tumors that can be treated by surgical excision. However, recurrences are frequently observed, and recurrent lesions tend to grow more rapidly than primary lesions. Although the etiology of pterygium and papilloma has not been established, human papillomavirus (HPV) is thought to be one of the causative factors. ${ }^{(29)}$ Another study found 
HPV in $50 \%$ of 10 pterygia with the same types as in conjunctival papillomas. They suggested that persistent conjunctival HPV may possibly play a part in the recurrence of pterygia post excision. ${ }^{(30)}$ In addition, Rodrigues et al. ${ }^{(20)} \mathrm{HPV}$ DNA in 21 of 36 pterygia in Brazil, along with abnormal 53 expression in 14 of the 36 specimens, and concluded that abnormal expression of p53 and HPV DNA are required co-factors for the development of pterygium.

The different and sometimes contradictory results of various studies and the fact that some features, eg. p53 mutations, were only found in a proportion of pterygia, may be due to differences in methodology and study populations. However, it may also be indicative of multiple causative factors, implying that the pterygium may not be a distinct disease entity but should rather be viewed as a final common outcome of various etiological factors, such as geography and ethnicity, with UV radiationinduced damage as the main factor. In connection with ethnicity, the variable findings of p53 protein expression in pterygia by several study groups might be explained by the observation that the frequency of p53 mutations in cancer can vary among different races. Ueda et al. ${ }^{(31)}$ demonstrated that the incidence of immunoreactivity for p53 is related to differences in development of pterygium with race as well as environmental factors.

\section{CONCLUSIONS}

From the abovementioned observations and theories it may be concluded that the pterygium remains an enigma, having the features of an exuberant growth but also those of a benign neoplasm. The previously held opinion that the pterygium is a degenerative condition should in all probability be revised, but not (yet) discarded. At present there is a plethora of data, but no unifying theory capable of explaining all of the characteristics of the pterygium. As both exuberant growth and benign neoplasm are essentially cellular proliferations, whether normal or aberrant, we have to a wait further studies for a solution to this interesting scientific puzzle.

\section{REFERENCES}

1. Coroneo MT, Di Girolamo N, Wakefield D. The pathogenesis of pterygia. Curr Opin Ophthalmol 1999;10:282-8.

2. Gazzard G, Saw SM, Farook M, Koh D, Widjaja $\mathrm{D}$, Chia SE, et al. Pterygium in Indonesia: prevalence, severity and risk factors. $\mathrm{Br} \mathrm{J}$ Ophthalmol 2002;86:1341-6.

3. Wong TY, Foster PJ, Johnson GJ, Seah SK, Tan DT. The prevalence and risk factors for pterygium in an adult Chinese population in Singapore: the Tanjong Pagar survey. Am J Ophthalmol 2001;131: 76-83.

4. Kanski JJ. Clinical ophthalmology: a systematic approach. $5^{\text {th }}$ ed. Butterworth-Heinemann: Edinburgh;2003.

5. Fuchs E. Uber das pterygium. Albert von Graefes Arch Klin Exp Ophthalmol 1892;38:1. Cited by Gheck L, Dupas B, Denion E, Amar N, Baudouin C. Apport de la microscopie confocale in vivo à l'étude des ptérygions. [Advantages of the in vivo confocal microscope for investigation of the pterygium]. J Fr Ophtalmol 2007;30:3-10.

6. Gheck L, Dupas B, Denion E, Amar N, Baudouin C. Apport de la microscopie confocale in vivo à l'étude des ptérygions. [Advantages of the in vivo confocal microscope for investigation of the pterygium]. J Fr Ophtalmol 2007;30:3-10.

7. Vogt J, Harrison BJ, Spearman H, Cossins J, Vermeer S, Cate LN, et al. Mutation analysis of CHRNA1, CHRNB1, CHRND, and RAPSN genes in multiple pterygium syndrome/fetal akinesia atients. Am J Hum Genet 2008;82:222-7.

8. Buratto L, Phillips RL, Carito G. Clinical anatomy. In: Pterygium surgery. Buratto L, Phillips RL, Carito GC, editors. Thorofare:Slack;2000.p.17-20.

9. Detorakis ET, Spandidos DA. Pathogenetic mechanisms and treatment options for ophthalmic pterygium: trends and perspectives. Intl J Mol Med 2009;23:439-47. 
10. Di Girolamo N, Tedla N, Kumar RK, McCluskey $\mathrm{P}$, Lloyd A, Coroneo $\mathrm{M}$, et al. Culture and chracterisation of epithelial cells from human pterygia. Br J Ophthalmol 1999;83:1077-82.

11. Pellegrini G, Traverso CE, Franzi AT, Zingirian M, Cancedda R, De Luca M. Long-term restoration of damaged corneal surfaces with autologous cultivated corneal epithelium. Lancet 1997;349: 990-3.

12. Dushku N, John M, Schultz GS, Reid TW. Pterygia pathogenesis: corneal invasion by matrix metalloproteinase expressing altered limbal epithelial basal cells. Arch Ophthalmol 2001;119: 695-6.

13. Tong L, Chew J, Yang H, Ang LPK, Tan DTH, Beuerman RW. Distinct gene subsets in pterygia formation and recurrence: dissecting complex biological phenomenon using genome wide expression data. BMC Med Genomics 2009;2:14.

14. Dushku N, Reid TW. p53 expression in altered limbal basal cells of pingueculae, pterygia, and limbal tumors. Curr Eye Res 1997;16:1179-92.

15. Weinstein O, Rosenthal G, Zirkin H, Monos T, Lifshitz T, Argov S. Overexpression of p53 tumor suppressor gene in pterygia. Eye 2002;16:619-21.

16. Schellini SA, Hoyama E, Oliveira DE, Bacchi CE, Padovani CR. Expressão da metaloprotease de matriz-9 no pterígio [Matrix metalloproteinase-9 expression in pterygium]. Arq Bras Oftalmol 2006; 69:61-4.

17. Schneider BG, John-Aryankalayil M, Rowsey JJ, Dushku N, Reid TW. Accumulation of p53 protein in pterygia is not accompanied by TP53 gene mutations. Exp Eye Res 2006;82:91-8.

18. Tsai YY, Cheng YW, Lee H, Tsai FJ, Tseng SH, Chang KC. P53 gene mutation spectrum and the relationship between gene mutation and protein levels in pterygium. Mol Vis 2005;11:50-5.

19. Perra MT, Maxia C, Corbu A, Minerba L, Demurtas $\mathrm{P}$, Colombari R, et al. Oxidative stress in pterygium: relationship between p53 and 8-hydroxydeoxyguanosine. Mol Vis 2006;12:136-42.

20. Rodrigues FW, Arruda JT, Silva RE, Moura KKVO. TP53 gene expression, codon 72 polymorphism and human papillomavirus DNA associated with pterygium. Gen Mol Res 2008;7:1251-8.

21. Ke M, Sun Z, Wang L. Expression of MMP-1, MMP-9 and TGF- $\beta 1$ in human pterygium and its clinical significance. FASEB J 2007;21:711-18.

22. John-Aryankalayil M, Dushku N, Jaworski CJ, Cox CA, Schultz G, Smith JA, et al. Microarray and protein analysis of human pterygium. Mol Vis 2006; 12:55-64.

23. Chui J, Di Girolamo N, Coroneo MT, Wakefield D. The role of substance $P$ in the pathogenesis of pterygia. Invest Ophthalmol Vis Sci 2007;48:44829.

24. Chiang CC, Cheng YW, Lin CL, Lee H, Tsai FJ, Tseng SH, et al. Cyclooxygenase 2 expression in pterygium. Mol Vis 2007;13:635-8.

25. Tsai YY, Cheng YW, Lee H, Tsai FJ, Tseng SH, Chang KC. P53 gene mutation spectrum and the relationship between gene mutation and protein levels in pterygium. Mol Vis 2005;11:50-5.

26. Park TK, Jin KH. Telomerase activity in pterygial and normal conjunctival epithel-ium. Korean J Ophthalmol 2000;14:85-9.

27. Aspiotis M, Tsanou E, Gorezis S, Ioachim E, Skyrlas A, Stefaniotou M, et al. Angiogenesis in pterygium: study of microvessel density, vascular endothelial growth factor, and thrombospondin-1. Eye 2007;21:1095-101.

28. Tekelioglu Y, Turk A, Avunduk AM, Yulug E. Flow cytometrical analysis of adhesion molecules, Tlymphocyte subpopulations and inflammatory markers in pterygium. Ophthalmologica 2006;220: 372-8.

29. Piras F, Moore PS, Ugalde J, Perra MT, Scarpa A, Sirigu P. Detection of human papillomavirus DNA in pterygia from different geographical regions. $\mathrm{Br}$ J Ophthalmol 2003;87:864-6.

30. Gallagher MJ, Giannoudis A, Herrington CS, Hiscott $\mathrm{P}$. Human papillomavirus in pterygium. $\mathrm{Br}$ J Ophthalmol 2001;85:782-4.

31. Ueda Y, Kanazawa S, Kitaoka T, Dake Y, Ohira A, Ouertani AM, et al. Immunohistochemical study of p53, p21 and PCNA in pterygium. Acta Histochem 2001;103:159-65. 